\title{
Leisure in old age: disciplinary practices surrounding the discourse of active ageing
}

\author{
By Jaroslava Hasmanová MarhánKová*
}

\begin{abstract}
In the 1990s, the World Health Organization adopted the term "active ageing", which currently represents a key vision of old age in Western societies facing the situation of demographic ageing. The meaning of the idea of active ageing is based on the concept of individuals actively and systematically influencing the conditions of their ageing through selfresponsibility and self-care. The aim of this article is to map how the idea of active ageing is constructed and the implications it presents with regard to the way in which seniors relate to their experience of old age. It concentrates on a specific segment of senior-oriented social services (centres for seniors that offer leisure time activities and educational courses) that represent an institutional context for the manifestation of the discourse of active ageing. A three-year ethnographic study was conducted in two such centres in the Czech Republic. The article focuses on various strategies for the disciplining of the ageing body. It points out that these disciplinary practices are an integral part of the daily running of the centres and that the seniors who intensively engage in them have internalised the idea of an active lifestyle as the most desirable lifestyle in old age. Active ageing was constructed by them as a project that must be

*Jaroslava Hasmanová Marhánková, Department of Sociology, University of West Bohemia, Czech Republic
\end{abstract}


International Journal of Ageing and Later Life

worked on. Through the "technologies of self" embedded in the imperative of the necessity to move or do something, they participate in the production of the discourse of active ageing as a form of discipline of the body. At the same time, the article outlines how the idea of active ageing as the "correct" form of ageing influences the self-conception of these seniors and their attitudes towards ageing and their peers.

Keywords: active ageing, ethnography, governmentality, leisure, lifestyle, third age.

\section{Introduction}

The current context of ageing is changing. On the one hand, these changes relate to the existence of more favourable socioeconomic conditions and continuing medical progresses, which make the lives of so many people better and longer. However, these changes are also taking place in the concepts of old age and its appropriate form (Tulle-Winton 1999: 282). The expanding consumer society celebrates all novelty as having the highest value, wherein youth itself has become a form of cultural capital (Gilleard \& Higgs 2000: 62-64). Hand in hand with these changes, the concept of "good" old age is also changing. This changed idea of old age is gradually becoming more connected to the need to stay young, both in the sense of activity (Katz 2000) and physical appearance (Biggs 2002; Coupland 2007; Featherstone 1991; Featherstone \& Hepworth 1991). As Katz points out (2000), nowadays activity represents an idealised image of ageing. This is also reflected in the dominant gerontological discourse and in the approach of professionals who deal with seniors. According to Katz, activity is becoming the key conceptual framework in the current perception of ageing. Furthermore, it also entails an ethical dimension, as it clearly defines activity as a universally desirable condition.

The concord between activity and ageing has also been translated into a more practical and pragmatic political programme under the label of "active ageing policies" (Vidovićová 2005: 344). The term "active ageing" is currently one of the most frequently used terms in gerontological studies as well as in national and international documents related to the issues of ageing. As Ney (2005: 325) points out, it has attained a prominent position 
in the European policy agenda. The idea of active ageing has been incorporated into the agenda of the World Health Organization (WHO) as well as that of the European Union and has become part of national social policy. The Czech government identifies active ageing as its first priority in the National Programme for the Preparation for Old Age. This new awareness of the concept of active ageing has also been influenced by organisations that offer services for seniors and influences the way providers construct the images of what old age should look like (Hasmanová Marhánková 2010).

In this article, an attempt will be made to describe the aforementioned changes in ageing policy and in the perception of the relationship between activity and old age. First, it focuses on the changing representations of old age that are currently affected by the idea of activity. It analyzes the discourse of active ageing as a strategy for disciplining the ageing population. Next, it focuses on the lifestyles of seniors who actively participate in the centres that offer leisure time activities designed only for seniors in the Czech Republic. The aim of this article is to map how the idea of active ageing is constructed and the implications it presents with regard to the way in which seniors relate to their experience of old age.

The data presented are based on an ethnographic study of two centres offering seniors-only leisure time activities and, further, on 47 interviews with clients and employees of these centres. These centres can be seen as places that strongly reflect the idea of active ageing as "correct ageing". In this article, I point out that disciplinary practices surrounding the ageing body are an integral part of the daily running of the centres, and that the seniors who intensively engage in them have internalised the idea of an active lifestyle as the most desirable lifestyle in old age and use various strategies to ensure that that they will constantly be active.

\section{Changes in the Representations of Ageing}

There is a long history of the association of old age with disease and passivity (Hazan 1994). In this respect, the concept of active ageing represents an interesting revision of the way the notion of old age should be constructed and what this concept means. The current primacy of the idea of active ageing must be understood in the context of, on the one 
International Journal of Ageing and Later Life

hand, negative representations of ageing and, on the other, the demographic trends that challenge them. Alan Walker (2010: 586-587) associates the representation of old age with the development of the welfare state. He points out the positive outcomes of the development of strong welfare states in Europe, which have markedly raised the living standards of individuals, but also highlights certain negative consequences with regard to the position of seniors. The strong association of seniors with the welfare state and their dependence on public pension schemes have contributed to the development of images of seniors as passive recipients and supported their exclusion from various spheres of social life. Walker refers to these processes as the "old public discourse on ageing". This discourse has, however, been substantially redefined since the 1970s, and such redefinition has gone hand in hand with a general rethinking of the role and functioning of the welfare state, especially in regard to present demographical trends in population ageing. These trends bring the sustainability of the current system into question. A "new public discourse on ageing" has gradually come into being, one that challenges the representation of old age as a time of passivity and presents it instead as a time in which the idea of activity can play a crucial role (Walker 2010).

Elderly people now represent a growing sector of the population and are thus becoming more and more visible. Increasing life-expectancy, together with the relatively low age of retirement, raise important questions regarding the place of old age in an individual's biography, as well as in the whole of society. The representation of old age as a time of inactivity, "rolelessness" and dependency are being confronted by the need to take advantage of the growing number of ageing citizens. The emergence of the concept of active ageing, which belongs to the area of social policy, can be seen as part of a wider change in the way the meanings of ageing are constructed and how the position of old age in individual biography is interpreted. Peter Laslett's (1989) concept of the third age represents a prominent resource for the redefinition of the representations of old age. The increase in life expectancy, together with the economic well-being of relatively "young" retirees, has created a new generation of retired people who can find new fulfilment in old age. Their independence of the labour market and the considerable amount of free time they possess enable them to develop new lifestyles. The third age thus 
constitutes an autonomous period of an individual's life that Laslett depicts in a very positive manner as a time of opportunities and fulfilment.

Laslett's theory is often criticised for being normative and ignorant of the barriers which certain social groups face in their fulfilment of the ideals of the third age (Bury 1995; Jones et al. 2008). Regardless of its apparent limitations, Laslett's concept is still important for an understanding of the current representations of ageing. The idea of the third age embodies a notion of the post-traditional life-course with an emphasis on selfdevelopment and individualism (Rubinstein 2002). As Gilleard and Higgs (2000: 38) suggest, the third age demands an "active construction of 'postwork' identity". This notion fits completely into the modern "project of the self" - a continuous effort and responsibility to (re)define one's self. At the same time, the third age is portrayed as a period when life is structured more freely and independently of the traditional structures of work and the state (Gilleard \& Higgs 2000: 28-39). Indeed, the consumption of lifestyles has become crucial for an understanding of the different cultures of ageing. According to Gilleard and Higgs (2000), retirement now represents an arena of heterogeneous experiences linked to various lifestyles.

The embedding of ageing in consumer society also has a significant impact on the representations of ageing. The concept of active ageing builds upon the social changes addressed by the aforementioned authors. It follows in the tradition of attempts which try to positively redefine the negative images of old age. The idea of active ageing transforms the ageing population from a burden to a benefit (Moody 2001: 176). According to Biggs (2001: 311), activity today serves as "legitimized fields of social inclusion". Positive images of ageing show seniors as autonomous individuals that achieve feelings of happiness and satisfaction, thanks to their participation in the labour market and their corresponding "productive" activities. In this respect, the active ageing policy significantly challenges the "ageistic" images of old age. Its primacy, however, raises important questions regarding its apparent normative dimension. We can ask whether these representations offer a real possibility to structure one's own ageing experience more freely, or whether only new normative images of ageing are proliferated. As Rudman (2006: 196) states: "as ideal subjectivities encourage people with adequate resources to free themselves 
International Journal of Ageing and Later Life

from ageist attitudes and aging bodies, they simultaneously create a new set of obligations associated with being autonomous, responsible and active 'retirees"'. Although Laslett, as well as Gilleard and Higgs speak of the experience of retirement in terms of heterogeneity and a new opportunity for fulfilment, both of these visions are based on the idea of an active retiree, both in the sense of active lifestyle and consumption. As Katz (2000: 140) points out, "the aged subject becomes encased in a social matrix where moral, disciplinary conventions around activity, health and independence appear to represent an idealized old age".

\section{Active Ageing as a Strategy for Disciplining the Ageing Population}

Despite the visible dominance of the concept of active ageing in current social policy, a definition of what it really means to age actively is present only implicitly. The idea of active ageing seems to be something so clear and taken for granted that there is no need to specify it explicitly. The most cited definition is that of the WHO, which very broadly defines active ageing as a "process of optimizing opportunities for health, participation and security in order to enhance the quality of life as people age" (WHO 2002: 12). This definition represents a very broad vision that attempts to represent various dimensions of life. However, documents published by the European Commission and the Czech government aspire to implement this idea into social policy work with a different concept of what it means to age actively. One of the few explicit definitions can be found in an article published by the European Commission. It defines active ageing as a strategy that "in practice means adopting healthy lifestyles, working longer, retiring later and being active after retirement. Promoting active ageing is about promoting opportunities for better lives, not about limiting rights" (European Commission 1999). The EU Council conclusions on active ageing state that "active ageing means creating opportunities for staying on the labour market longer, for contributing to society through unpaid work in the community as volunteers or passing on their skills to younger people, and in their extended families, and for living autonomously and in dignity for as much and as long as possible" (Council of the EU 2010: 5). Despite also 
including a reference to an autonomous and dignified life, the main emphasis is still placed on paid (or unpaid) labour.

A very similar and even narrower approach can be found in the document published by the Czech government. Although the Czech government has established active ageing as its first strategic priority in the National Programme for the Preparation for Old Age for the years 20082012, there is no single definition of what active ageing means in the document (henceforth referred to as the Czech National Programme). Nevertheless, it implicitly refers to a concept that is very similar to the definition cited on the web page of the European Commission: the whole section devoted to the priority of active ageing focuses on seniors' participation in the labour market and the process of lifelong learning. The view of lifelong learning in these paragraphs refers strongly to the human capital theory, according to which the goal of additional education lies primarily in the enhancement of the value of the labour force (Slowey 2008). To conclude, although there exist more comprehensive definitions of active ageing (e.g. the one used by the WHO) in social policy, it is conceptualised mainly as an issue relating to an ageing work force (Perek-Bialas et al. 2006).

The identification of active ageing with seniors' participation in the labour market and lifelong learning can be understood within the context of the concept's creation. The process of demographic ageing represents a crucial framework for current social policy related to the issues of ageing and elderly people. Although there has been a marked change in the narrative dealing with ageing populations towards the idea of opportunity (Biggs 2001), the demographic changes are still depicted via the rhetoric of risk. The growing number of seniors in the population is something that has to be dealt with; it is something that poses a challenge and that, in any case, demands the need for action. The challenges brought about by demographic ageing result in the need to keep the senior population on the labour market for as long as possible. The concept of active ageing provides a conceptual tool for such social policy (Rabušic 2008). As the report published by the European Commission states: "Europe's best chance for addressing the challenges of population ageing depends on making full use of the potential of older people, which will require the promotion of active ageing" (Council of the EU 2010: 5). The risks need to 
International Journal of Ageing and Later Life

be controlled and active ageing is depicted as a strategy that presents a solution. This solution is connected with effectiveness - effectiveness of management of one's own health, thanks to an active and healthy lifestyle, which will simultaneously lead to the effective reduction of healthcare costs and above all to the effectiveness of the economy. As the Czech National Programme (paragraph 4.2) points out in a quite radical way, "people have to be healthier and more satisfied so they are able and more willing to stay employed for a longer period". The Council of the European Union makes a similar point: "Europe's future economic competitiveness and prosperity depends crucially on its ability to fully utilize its labour resources" (Council of the EU 2010: 4). The participation in the labour market is thus constructed as some kind of therapy - a cure not only for seniors who can be appreciated as productive members of society but above all for society itself, which has to challenge the "risk" of demographic ageing.

\section{Ageing, Responsibility and the Management of Self}

The rhetoric of risk connected to demographic trends that surrounds the debate about active ageing also substantially influences the position of the individual. Phillipson (1998: 19) suggests that "attacks on the burden of the elderly population were seen to legitimize a transfer of responsibilities from the state to individual older persons". The idea of active ageing is based on the concept of individuals who actively and systematically influence the conditions of their own ageing. This process of individualisation of responsibilities is very visible in the Czech National Programme (paragraph 2.7), which states that "people at a productive age... are responsible for their own preparation for ageing and old age" and that "the dignified and active position of elderly people in society results from, among other things, their active contribution and responsibility for their own life". The concepts accentuated by the idea of active ageing, such as self-responsibility and self-care, weaken the contract between an ageing individual and the state. Responsibility is shifted from the state to social actors on the micro-level, such as professional experts and older people themselves (Phillipson \& Powell 2004). By means of their active lifestyle, 
individuals accept the responsibility for their own quality of life in old age. As Oancea (2008: 1) states: "it is now widely accepted that passivity and disengagement increase the risk of chronic health problems in retirement, and that the promotion of social engagement among older people is a sensible component of public health strategies designed to contain rising health and social costs." Activity is thus presented both as a path to healthy and happy ageing, and as an integral part of seniors' responsibility towards themselves. It is at the same time viewed as something that can and should be managed. Thanks to their activity, seniors can withdraw from the negative image of ageing and become "good" citizens (Hepworth 1995; Rudman 2006). Powell (2006: 31) points out that this shift in responsibility has serious implications for those who are not responsible enough or are not attempting to be responsible in the proper manner. The individualisation of responsibility ignores the structural nature of social problems as well as the wider social context that shapes individuals' resources, choices and possibilities.

The conceptualisation of active ageing as a form of proper civil responsibility is part of the process of disciplining the population. Foucault (1994) uses the term "governmentality" to depict the shift in the ways power is employed in the modern state. This kind of power makes it possible to regulate the population of (not only) elderly people using various apparatuses of security (Powell 2001: 128). "It is the population itself on which government will act either directly, through large-scale campaigns, or indirectly, through techniques that will make possible, without the full awareness of the people, the stimulation of birth rates, the directing of the flow of population into certain regions or activities, and so on" (Foucault 1994: 217). Active ageing represents one of these techniques, which encourages elderly people to use various self-management practices to manage the risk of ageing (Powell 2006). In the discourse of active ageing, the ageing body is disciplined through activity. It is perpetual selfsurveillance that produces the ideal ageing subjectivity. Its aim is to produce "docile" bodies (Foucault 1979). The responsibility to remain active, which is presented as private self-responsibility towards one's own health, is at the same time the responsibility towards others and the social 
International Journal of Ageing and Later Life

system, which otherwise faces the burden of a growing number of dependent citizens.

The process of governmentality is not something external to individual subjectivities. Older people govern themselves (Powell 2001: 128). People are actively engaging in the production of these discourses and, through the "technologies of self", mobilise structural discourses (Powell \& Biggs 2003). The idea of active ageing is translated into particular lifestyles that refer to the available discourses but also modify them and resist them. The discourse of active ageing poses new demands on the ageing body. Katz (2000) uses the term "busy bodies" to show how the ageing body is constantly disciplined through the idea of activity that is presented as a path to happy and desirable ageing. The imperative of activity penetrates gerontological knowledge, social policy and social work and is a crucial component of the disciplinary discourse surrounding elderly people. The next section of this article focuses on the way in which seniors relate to activity. It outlines various strategies through which activity is incorporated into the lifestyle and management of the daily life of a specific group of seniors who regularly participate in the centres for seniors in the Czech Republic.

\section{Methodology}

The data presented in this article are part of a three-year ethnographic research project conducted in the Czech Republic. It focused on a specific group of seniors who are engaged in centres that offer leisure time activities specifically for seniors, as well as on the providers of these services. This segment of senior-oriented social services represents an institutional context for the manifestation of the discourse of active ageing. In the second half of the 1990s, specialised centres for seniors emerged in the Czech Republic, which declared the aim of enabling seniors to spend their free time actively. These centres offer lectures, learning courses, exercise programmes and other activities. Their participants are solely elderly people. The clients are very homogeneous in terms of their education; the vast majority have secondary school education, frequently even higher degrees. All are older than 60 years of age and have retired. 
Women form the majority of clients of these centres. Based on my observations at two of these centres, since official statistics are not available, I estimate the proportion of men attending the activities of the centre to be at most only $10 \%$ of all clients. The operation of these centres is based on shared premises and the structure of their activities is very similar. These centres can be seen as an example of the manifestation of the discourse of active ageing. They strongly adhere to ideas of independence, self-responsibility and activity and they also try to offer a positive vision of ageing based on an active lifestyle.

A three-year ethnographic study was conducted in two such centres in the Czech Republic. Two centres were chosen in different parts of the Czech Republic to map possible variations with regards to the number of inhabitants in the cities where the centres are situated. The research began at a Prague centre in December 2006. The second centre is located in the Zlín region, in a town with approximately 30,000 inhabitants. The distinct locations and sizes of the centres were chosen because of the possibility of comparing the differences in the daily working of the centres and their clients. The research shows, however, that these centres present a very similar environment with a similar structure of clients and activities, as well as clients' and employees' approaches to services. ${ }^{1}$ The largest group in both centres is clients who are between 60 and 70 years of age.

\footnotetext{
${ }^{1}$ To ensure the greater anonymity of my informants, I decided not to refer to the particular centres when quoting the clients or employees. The centres represent closed environments. To avoid the risk of identification of clients or employees within the institutions, I refer to them using only pseudonyms and age. Women represent the majority of the staff. Since one of the centres only has one male employee, I use only female pseudonyms to identify the employees so as to ensure his anonymity.
} 
International Journal of Ageing and Later Life

The intensity of the fieldwork in these centres varied due to their distance. The most intensive fieldwork was conducted in the Prague centre during an intensive three-year period. The method of participant observation was used and various documents of the centres were analysed. The data were supplemented with 20 in-depth interviews with randomly selected clients of the centre (17 women and 3 men) and 11 of its employees. ${ }^{2}$ During the research period, at least two days a week were spent in the centre, and at least two hours a day. As a volunteer, I also had the possibility to actively participate in the running of the centre. The research at the second centre began in 2009. Due to the location of the centres, this part of the research was conducted during an intensive one week stay. Throughout the week, the daily operation of the centre was observed. Additional semi-structured interviews were conducted with 14 randomly selected clients (13 women and 1 man) and with two employees of the centre. ${ }^{3}$

Analysis in ethnographic research cannot be separated from the process of data production. As Ezzy (2002: 73) points out "many choices during data collection are integral to how the data are analyzed and will be analyzed". These choices include, for example, the decisions concerning who to interview or on what aspect to focus. My approach to data analysis

\footnotetext{
${ }^{2}$ The first interviews were conducted after a two-month period that allowed me to meet the staff and become familiar with most of the clients and the daily running of the centre. The in-depth interviews lasted on average an hour and a half. I tried to capture the variability of the experience of the clients and employees. Clients attending different courses and programmes were contacted. All of the employees directly engaging in the organisation of leisure activities were interviewed.

${ }^{3}$ Due to the short length of the stay in the second centre, a design of semistructured interviews was chosen. My relationship with the informants in the centre in the Zlin region was different compared to the Prague centre. The design of semi-structured interviews helped me to better manage the interviews with people who I had met for the first time and gave me enough space to eventually redefine the questions. These interviews lasted on average half an hour. Clients were contacted in the centre with the help of my key informant the head of the centre. This centre had only two regular employees, both of which were interviewed.
} 
followed the steps outlined by Emerson et al. (1995: 142-158). It started with the reading of the filed notes and interview transcriptions and was followed by the open coding and writing of initial memos. The principles of thematic analysis (Ezzy 2002: 86-94) were used during coding to identify key themes. These focused mainly on the various meanings of activity and its role in the centres.

The next section of this article focuses on the way in which seniors relate to activity. It outlines various strategies through which activity is incorporated into the lifestyle and management of the daily life of a specific group of seniors who regularly participate in the centres for seniors in the Czech Republic.

\section{Engagement in the Centres and the Role of Activity}

The idea of "activity" represents a key conceptual framework for the philosophy of centres offering leisure time activities for seniors. They refer to activity in all their documents and promotional texts. For example, the centre in the Zlín region uses the slogan "by means of activity we fight against ageing". Clients use the word activity to refer to their engagement in the centres; activity can thus for instance mean participation in a language course or a lecture. The activities offered by the centres played an important role in the daily lives of the clients and also affected the manner in which they viewed their old age. Most of my informants actively participated not only in the centres studied but also in other various centres and activities that were aimed at seniors. Their participation in these activities became a highlight of their everyday life. When searching for information about leisure time activities, my informants focused particularly on activities designed specifically for seniors.

All the participants suggested two main reasons why they only make use of these kinds of services. The first reason was their financial situation. Courses and activities offered by the centres are two or even three times cheaper than similar courses in private organisations, mainly due to the engagement of volunteers. The second main reason that was accentuated especially by seniors attending educational (Internet and language) courses was the age-homogenous social interaction. The centres are age-segregated environments. Only people of a certain age are allowed to participate. This 
International Journal of Ageing and Later Life

segregation has a socially problematic potential. Age-segregation promotes ageism and insensibility to other age groups. Concurrently, participation in organisations that register members of different ages is one of the crucial mechanisms of age integration (Uhlenberg \& de Jong Gierveld 2004). Nevertheless, this research shows that informants perceived this agesegregated environment as an advantage. They referred especially to the more friendly and relaxed atmosphere and less emphasis on achievement. They often had some experience with "ordinary" language or Internet courses. However, this experience was mostly negative. My informants felt embarrassed among younger colleagues because they "were not able to learn as fast as they did". Further, they stressed that seniors have their own "special needs" related to the utilisation of skills and to the approach of their teachers, as they often mentioned that especially in the case of languages they would never be able to learn to speak well and that they wanted only to feel more safe abroad during holidays, while they felt that teachers also "have to be patient". Several informants also mentioned that they felt uncomfortable among other students because they were not able to respond to discussed topics that are related to young people's interests. They often felt partially excluded from the collective. Age-homogenous groups provided them with a safer environment for learning and expressing their interests. ${ }^{4}$ Since specialised services for seniors only became available rather recently, my informants often had experience with activities in age-heterogeneous collectives, but after entering these centres, they engaged solely in the centres' activities. This fact can suggest a potentially growing tendency towards age-segregation in later life.

\footnotetext{
${ }^{4}$ This declared preference for an age-homogenous collective nevertheless did not mean the rejection of the presence of young people. On the contrary, most of the clients mentioned that they enjoy being accompanied by younger people and they appreciate the teachers who were not recruited from amongst their peers. Being a volunteer in one of the centres, I was on many occasions praised as someone bringing "fresh air" to the environment. The clients referred to my age as an added value. The preference for an age-homogenous collective referred to the co-participants who engaged in the same activity. The presence of their peers was perceived by them as something that brings freedom from constant comparison with the achievements of their younger fellow students.
} 
As mentioned earlier, when searching for information about leisure time activities, informants focused only on activities for seniors. They did not limit themselves only to one or two types of activities but, on the contrary, took on more and more activities. Their weekly programme was filled with at least one activity a day, and the services offered became the "time schedule" for their everyday lives. The importance of these activities for shaping their lives can be demonstrated by Mrs. Hana's (aged 71) attitude, who regularly records all the activities attended in each particular month. The possibility to participate in such activities was strongly connected to their transition into retirement, which was depicted in a very positive manner. When talking about their retirement, my informants stressed the ability to structure their free time independently of the demands of their work description. They often explicitly mentioned that they were able to work and that they felt no serious constraints because of their age regarding work, but they wanted to have some time for themselves. The transition to retirement was constructed as a transition to a new way of structuring their free time. On several occasions, I heard a common phrase that referred to this change - "I don't have to do anything, but I can do anything I want". The imperative "have to" was associated with their work description; the verb "can" with their current lifestyle.

\section{Activities and Time Structuring}

Although my informants presented their transition to retirement as an unproblematic event, a closer look at their narratives reveals that this transition represents a more complicated process. The previous time structures of their everyday lives had suddenly disappeared. On the one hand, this was a desired and welcomed event. On the other hand, this event posed new demands on the informants regarding their free time, which had suddenly lost its definition. Mrs. Vilma (aged 61), for example, mentioned:

\footnotetext{
It is an advantage of retirement that you can do what you want to do but you don't have to do anything. Sometimes it is an advantage, because you are not disciplined. But you, at the same time, suddenly miss the certainty - I have to go to work, I have to do this and that. You are the architect of your own time.
} 
International Journal of Ageing and Later Life

This change was in many respects perceived as a burden. My informants felt the need to somehow replace the disappearing structure of their free time. Although they presented their lifestyle as purely voluntaristic, at the same time they implicitly or explicitly stressed that they had to be active and take part in the activities. Mrs. Helena (aged 63) for instance said that "if I had just sat at home after I retired, my life would have only meant waiting around for death". Mrs. Pavlína (aged 63) mentioned with regards to her health: "If I did not take part in these activities I would totally deteriorate". Although the informants emphasised their freedom from the imperatives of "I have to" that were connected mainly with work and family responsibilities, simultaneously there was another imperative present which replaced "have to do this and that" with a more abstract "have to do something". In this respect, centres for elderly people offered an alternative frame for new time structuring.

These activities became so important for the informants' everyday life that they often centred their other programmes on these activities. The activities represented fixed points in their daily lives. The schedule of activities is constant and planned in advance, and thus serves as an important mechanism of time structuring as well as a motivation for activity itself. Course activities are also paid for in advance. This provides strong motivation for regular participation. As one of my informants, Mrs. Zita (aged 74), mentioned:

It [i.e. activities of the centre] gives me some sense of continuity. I sometimes say to myself - I never missed a lesson; today I would rather stay at home. But I know that the moment I miss a lesson, I will stay at home all the time. You have to be strict with yourself. You have to move as long as you still can. This is the principle of paying for the courses in advance.

The motive of the necessity to "move" that is ensured by the fixed activities was apparent in many other interviews. Activities of the centres also guaranteed continuity with the lifestyle of productive age. Mrs. Olina (aged 64) stated that "if someone has no activities in old age, he/she has no reason to even dress well". The participation in the centres and their activities was also a part of self-discipline. When describing their everyday lives, my informants often mentioned the necessity to plan their day in advance in relation to the programme of their centre. They often live in 
remote parts of the cities and have to plan precisely their daily schedule to effectively manage all the activities. Mrs. Hana (aged 67) mentioned:

\begin{abstract}
At the end of the day I'm really tired and I have to sometimes persuade myself to go to the city museum [where lectures for seniors are held], where the activities start at half past four. So I also have to find some activity that starts at three o'clock, because at four it is almost dark outside and that really demotivates you to go out. I think that laziness is my biggest problem. If you sit at home a lot, then you just get lazy and stop wanting to go out.
\end{abstract}

Mrs. Hana thus structured her daily programme according to activities for seniors to make her daily schedule as effective as possible. She planned the activities in such a way that they ensured that she would stay active and take part in them.

\title{
Active Ageing as a Project - Activity as a Means and End
}

The lifestyle of the clients reflected the internalised notion of active lifestyle as a desirable model to follow. When talking about their life in retirement, they constructed their representations of ageing based on free time spent actively, accompanied by statements such as "I definitely have no time to be bored" (Mrs. Vlasta aged 66). However, this active lifestyle was, by the employees and clients, not perceived as something that was acquired casually. It was something that one had to struggle for. As Mrs. Hana (aged 67) pointed out later:

\footnotetext{
... retirement can be quite pleasant but you have to try, you have to push yourself. You can't fall, so to speak, into lethargy and just sit at home waiting for someone to do something for you. You have to be active a bit, search for the information in a newspaper or on the internet.
}

Active ageing was presented by the clients and employees as a result of individual intensive effort, which involved also a considerable amount of self-denial. This effort was compensated by the positive feeling of being successful, which meant, in this case, being active. As Mrs. Helena (aged 63) stated: 
International Journal of Ageing and Later Life

\begin{abstract}
I have overcome my laziness. That makes you happy. You are tired, but happy and in a good mood, because I can say to myself again: I have overcome my big laziness again and have done it again. It is... you sometimes really don't want to go, but when you overcome this, you feel good, so it is good. I don't know... I would also like to try going swimming regularly.
\end{abstract}

As Katz (2000: 147) points out, "remaining active as a resource for mobility and choice in later life is a struggle in a society where activity has become a panacea for the political woes of the declining welfare state and its management of the so-called risky population". Activity became a means and an end at the same time. As was pointed out in the previous section, lifelong learning is, in social policy, strongly connected to the labour market and the processes of enhancing one's qualifications. However, the informants involved in the research stressed the different conceptualisation of purposes for attending lifelong learning courses offered by the centres. In the interviews, participation in these activities was mostly described as an integral part of an active lifestyle. The possibility to use the knowledge gained in the courses in the future, as emphasised in lifelong learning policies, was marginalised. My informants stressed the motive of "movement" instead. This notion of the necessity to be continuously "on the move" points out the internalisation of the images of activity as a fundamentally positive moment of retirement. Despite the fact that many informants described the transition to retirement as a transition to a period when they could enjoy their free time without restraints, this freedom was in many respects limited by the notion that one simply has to do something. Courses offered by the centres were part of this self-discipline.

The concept of activity as a project was shared also by the employees of the centres. Although the centres offered very specific courses, mainly educational ones as well as sports, the value of participation was not seen by the employees in the transmission of the actual content of such courses but rather in activity itself. The employees interpreted engagement in the centres mainly as the success of seniors in the project of remaining active. They perceived activity not as a self-evident part of old age. At the same time, the activity was constructed as a means to happy ageing as in the case of an employee of one centre, Mrs. Lucie, who characterised the clients as follows: 


\begin{abstract}
They particularly want to go outside, meet people and talk with them. They don't want to stay alone and, because they push themselves and go there, they remain active. Just this and even the movement itself help them. Maybe lots of people don't even know about it [the centre]. Or they have become lazy. But if they overcome this they are then truly happy and their lives are suddenly different. To sit at home and, I don't know, just go for a walk with the dog - this is rather empty and stereotyped.
\end{abstract}

Mrs. Lucie in this quotation refers to activity as a factor that can substantially change life in old age. But not all activity is defined as relevant. There is a hierarchy of activities constructed in which some activities are defined as valuable, such as for instance participation in the centre, while others are not even acknowledged as activities at all, such as being at home or going for a walk with the dog.

Employees constructed the centres as mediators of an active lifestyle that offered clients the possibility of continuing in their "productive life". An employee of the centre, Mrs. Iva, mentioned that "they [the seniors] are motivated [due to their engagement in the centre] to wash up, dress up, put on make-up, think if their handbags are not too old-fashioned. In other words, they return to their productive age". The disciplinary practices surrounding the discourses of active ageing presented by the centres imposed a specific set of demands on the clients. These demands refer on the one hand to the necessity "to move" or, in other words, to be active in a proper sense, since - as outlined earlier - not every activity was recognised as a proper one. On the other hand, the bodies of clients were constantly disciplined by the demands that arose from their participation in centres designed for active seniors. Employees of the centres often highlighted this special status of their clients. As Mrs. Marketa, an employee of the centre, mentioned while looking at a couple of women clients with perfect makeup waiting for the start of their English class: "this is not a place where you can see old grannies, these women are real ladies". Clients of the centres were expected to care about their appearance. This care was at the same time presented as an inherent positive value of the activities of the centres. As Julia Twigg (2007: 295) points out: “Older people are thus caught within an altogether harsher moral climate in relation to dress ... a climate that disciplines and judges their bodies more strictly than those of younger people". Any lapse of dress can be interpreted as a signal of 
International Journal of Ageing and Later Life

mental and physical decline. In the case of the clients of the centres, this discipline was reinforced by their status as representatives of actively ageing seniors. Their superior positions as those "remaining active" or as "ladies" went hand in hand with the ability to demonstrate their capacity to represent a positive model of ageing. This model was closely linked to the model of productive age, in which activities substituted the fixed structures of working life. As employee of the centre, Mrs. Bohumila suggested: "it is good for them [the clients] that they have some daily activity, that they have to dress up, that they have something which is similar to their work". An appropriate appearance was part of this model, which leaves little space for any deviation that would signal any health problems or any impact of the process of ageing.

\section{"Crown of Life" - Seniors' Representation of (Active) Old Age}

While talking about ageing, my informants shared a specific concept of ageing that was based on a very positive image of life in old age. They described their everyday active lifestyle as full of activities and searching for something new. My informants rejected the image of old age as a period that does not bring anything new and, instead, emphasised the image of old age as a time that should be filled with activity. Their representation of life in retirement embodied the idealisation of old age as a period of independence and free time as it is reflected in the concept of the third age. This image can be seen also in the narrative of Mrs. Jarmila (aged 67):

\footnotetext{
It is a wonderful feeling [to enter retirement], really wonderful. I don't know if everyone feels it the same or they maybe wouldn't call it such, but it is a kind of liberation, final freedom ... I used to have to wake up at half past five, rush to work, I had to come on time, be prepared, then quickly come back home and, I don't know, take care of the children. There is a lot you have to do. You have a permanent feeling that you have to do this and that, that you are not completely free and this makes you tired. So that's why it [retirement] brought a feeling of freedom.
}

As in the case of Mrs. Jarmila's narrative, other clients also stressed the comparison to their previous life history. They often referred to their previous life history to explain why they so much enjoy their present lifestyle. They compared their current way of life to the period of their 
"productive" life, which was centred on their family and work responsibilities. Old age in this model stands out as a time that can be truly devoted to the clients' own interests. This comparison was reflected also in the interview with Mrs. Petra (aged 69):

\begin{abstract}
I always had a lot of hobbies and I always regretted that I could not devote myself to them, because I was employed and my job was quite time-consuming. So I was really looking forward to retirement. I retired when I was fifty-five because I had two children and the usual time for retirement was at fifty-seven. I felt unbelievably fresh at that time and I was not tired at all. I was so happy that I had time for everything I had always wanted to do.
\end{abstract}

Retirement was perceived as a well-earned rest and a time for selffulfilment. As Gilleard and Higgs (2000: 23) suggest, in the past retirement was perceived as "enforced choice connected to a decline of productivity or the need to remove older cohorts from the workforce". Now it is constructed as a potential "crown of life", primarily in terms of leisure and self-fulfilment. This does not mean that the clients of the centre did not express anxiety over the process of ageing. There was a distinct fear present constantly during the interviews that manifested itself in the threat of health problems and, in the worst case, the possibility of dementia, which would mean an end to their current lifestyle based on activity. This fear was, however, also presented as a driving force for their activity. As Mrs. Milena (aged 72) noted: "I have to enjoy life to the full while I still can".

The seniors' activity - most of the clients of the centres regularly participate in about three or more activities for seniors a week represented an important component of their construction of the positive representation of ageing. It was activity that was used to highlight the positive aspect of the experience of old age, which was contrasted to the stereotypical images of old age characterised by dependency, loneliness and passivity. As, for example, Ms. Milena (aged 80) mentioned:

I can't say I'm living some unhappy desperate life. I don't and I hope I don't look like this. My friend always says: do you know why I like you so much - because of your optimism. That you aren't so grumpy. Like some of these widows who just complain [she imitates the desperate style of talking]: 'I can't live without my husband, I'll hurt myself, I can't live that way anymore.' That is not my style. I have to find something in 
International Journal of Ageing and Later Life

my life that I will enjoy, that I will be interested in. I just don't want to get stuck only looking through the window and gossiping.

There was also a strong sense of a "we" constructed among my informants. For example, Mrs. Alena (aged 68) mentioned: "we [the participants in the English class organised by the centre] are very similar, we are ... how to put it ... we have such a progressive attitude. We are, as people call it now, "in"'. This "we" referred to the clients of the centres and more broadly to seniors who are active. It related primarily to the willingness and ability to stay active in old age. As one of my informants, Mrs. Ludmila (aged 72), said: "After some time you get to know everybody. It's always the same people at the activities. Soon you know all of them, at least their faces". The word "everybody" in this interview referred to the active seniors. The participation in the activities thus created a kind of a community. The members of this community - seniors with active lifestyles - were at the same time constructed as a specific group that is separated from "other" seniors. While talking about seniors in general, my informants often used very ageist images of ageing. This "we" was very exclusive and was not applied to all seniors in general. The participation in the activities for my informants constituted a crucial mechanism for the construction of this group identity. Their ability to participate in various free time activities and courses as well as the capability to help actively with their realisation served as a way to distinguish themselves from less active people or people with mental and physical disabilities. The participants perceived these less active people as "really" old. Activity thus became a central point in the construction of the identity of old people.

My informants demonstrated their resistance towards the stereotypical image of passive old age by means of the activities that, as was stated in the previous section of this article, are closely connected to the current idea of "good" old age. This does not mean, however, that the informants rejected the stereotypical images of ageing. They often talked about the experience of ageing in a very stereotypical and ageistic manner when speaking about this experience in general or when speaking about "other" elderly people. Activity in their case served to construct an idealised picture of positive old age that was personalised and seen as exceptional. These strategies show seniors as active participants in the construction of 
the discourse of active ageing and its superior positions. They mobilise the idea of activity to create a positive vision of ageing and use it as a resource for increasing self-esteem. The discourse of active ageing posits elderly people as autonomous, active and independent subjects. Such representation of seniors represents a significant change in the ways elderly people have traditionally been perceived. As shown earlier, the idea of active ageing enables elderly people to relate to their ageing in a very positive manner by means of activity. However, the superior position of active ageing and the stigmatisation of other lifestyles in old age that goes hand in hand with it raise important questions concerning the inequalities based on the ability or willingness to age actively. As Biggs (2001: 314) suggests, current discourses surrounding ageing "create a narrative that is facilitative for older people with the ability to finance a 'midlife style' and want, or have the physical or mental capacity, to participate in the existing social institution". Although the discourse of active ageing challenges the ageism that depicts elderly people as passive and dependent, it offers social inclusion only for a certain group of seniors. This raises a number of further issues regarding the construction of new inequalities in old age based on activity.

\section{Conclusion}

Current demographic trends have a fundamental impact on many aspects of society. The prominence that ageing has gained in the debates about these trends also influences the way the representations of ageing are constructed. Clear ideas of what constitutes old age and how it should develop are being formulated both at nationwide levels and within individual organisations. The idea of active ageing brings a positive vision of ageing that in many respects confronts the ageist picture of old age as a time fraught with passivity. In international as well as Czech social policy, it is widely accepted as a strategic vision of ageing in present society. The dominance of the discourse of active ageing has to be understood in the context of dilemmas arising from the fear of the growing number of seniors in the population. This article analyses the idea of active ageing as a set of disciplinary practices. The responsibility to remain active is presented not only as a private self-responsibility towards one's own 
International Journal of Ageing and Later Life

health but also as a responsibility towards others. An active lifestyle is constructed as a superior way of life that should be supported by the state. The discourse of active ageing thus presents significant dilemmas. It is productive in the way that it offers an opportunity to resignify negative images of ageing and provide an important resource for increasing selfesteem. However, it imposes another new set of requirements on seniors. The imperative to stay active inherently contains an ethical dimension where being active means also being a good citizen (Hepworth 1995; Rudman 2006).

The interviews with seniors show that the seniors who participate in the studied centres internalised the idea of active lifestyle as the most desirable lifestyle in old age and used various strategies to ensure that their body would be constantly active. Active ageing was constructed by them as a project that must be worked on. Through the "technologies of self" embedded in the imperative of the necessity to move or do something, they participate in the production of the discourse of active ageing as a form of discipline of the body. At the same time, the article outlines how the idea of active ageing as the "correct" form of ageing influences the selfconception of these seniors and their attitudes towards ageing and their peers. Participation in the activities served as an important mechanism of group identity construction. This identity is at the same time constructed in strict opposition to "other" seniors who are not active and who are perceived by these seniors in a very ageist manner. The active lifestyle embodied in the idea of active ageing offers a positive representation of ageing that has become a significant resource for increasing self-esteem for the clients of the centre. In this aspect, the idea of active ageing represents a welcome change in the way old age has traditionally been constructed. However, the close connection between activity and old age epitomised in the discourse of active ageing represented by the centres poses a new set of demands on ageing subjectivities and bodies that can exclude some individuals from the possibility of participating in these representations. The resource for increasing self-esteem promised by the idea of active ageing is not available to everyone, although it is often presented in social policy as a path which all responsible citizens should follow. The general problem of inequalities that could be invoked by the inclusiveness of this model is thus worthy of our attention, particularly if we consider the 
connection between the model of active ageing and the current dominant ideas of what constitutes "proper" old age.

\section{Acknowledgements}

The research was supported by the Czech Science Foundation - GACR (Grantová agentura Ceské republiky), grant number 403/09/0038. The author thanks the two anonymous reviewers and the editor of the International Journal of Ageing and Later Life for their valuable comments on the manuscript.

\section{Corresponding Author}

Jaroslava Hasmanová Marhánková, Department of Sociology, University of West Bohemia, Univerzitni 8, 30614 Pilsen, Czech Republic. Email: jmarhan@kss.zcu.cz

\section{References}

Biggs, S. (2001). Towards critical narrativity. Stories of ageing in contemporary social policy. Journal of Aging Studies 15(4): 303-316.

Biggs, H. (2002). The ageing body. In M. Evans \& E. Lee (eds.), Real Bodies. A Sociological Introduction (pp. 167-184). Houndmills: Palgrave.

Bury, M. (1995). Ageing, gender and sociological theory. In S. Arber \& J. Ginn (eds.), Connecting Gender and Ageing (pp. 15-30). Buckingham: Open University Press.

Council of the European Union (2010). Council conclusions on active ageing. The council of the European Union. Available on http:// www.consilium.europa.eu/uedocs/cms_data/docs/pressdata/en/lsa/ 114968.pdf (Accessed: July 20, 2010).

Coupland, J. (2007). Gendered discourses on the "Problem" of ageing: Consumerized solutions. Discourse and Communication 5(1): 37-61.

Emerson, R. M., Fretz, R. I. \& Shaw, L. L. (1995). Writing Ethnographic Fieldnotes. Chicago: The University of Chicago Press.

European Commission. (1999). New Paradigms in Ageing Societies. European Commission. Available on http://ec.europa.eu/employment_ 
International Journal of Ageing and Later Life

social/soc-prot/ageing/news/paradigm_en.htm (Accessed: March 24, 2010).

Ezzy, D. (2002). Qualitative Analysis. Practice and Innovation. London: Routledge.

Featherstone, M. (1991). The body in consumer culture. In M. Featherstone, M. Hepworth \& B. S. Turner (eds.), The Body (pp. 170-196). London: SAGE Publications.

Featherstone, M. \& Hepworth, M. (1991). The mask of ageing and the postmodern life course. In M. Featherstone, M. Hepworth \& B. S. Turner (eds.), The Body (pp. 170-186). London: SAGE Publications.

Foucault, M. (1979). Discipline and Punish: The Birth of the Prison. USA: Vintage Books.

Foucault, M. (1994). Governmentality. In J. D. Faubion \& P. Rabinow (eds.), Michel Foucault. Power (pp. 201-223). New York: The New Press.

Gilleard, C. \& Higgs, P. (2000). Cultures of Ageing: Self, Citizen and the Body. Harlow: Pearson Education.

Hasmanová Marhánková, J. (2010). Konstruování puedstav aktivního stárnutí $\mathrm{v}$ centrech pro seniory [To age actively. The construction of the idea of active aging in Czech Republic]. Sociologický časopis/Czech Sociological Review 46(2): 211-234.

Hazan, H. (1994). Old Age: Construction and Deconstruction. Cambridge: Cambridge University Press.

Hepworth, M. (1995). Positive ageing. What is the message? In R. Bunton, S. Nettleton \& R. Burrows (eds.), The Sociology of Health Promotion: Critical analysis of consumption, lifestyle and risk (pp. 176-190). London: Routledge.

Jones, I. R., Hyde, M., Victor, C. R., Wigging, R. D., Gilleard, C. \& Higgs, P. (2008). Ageing in a Consumer Society. From Passive to Active Consumption in Britain. Bristol: Polity Press.

Katz, S. (2000). Busy bodies: Activity, ageing and the management of the everyday life. Journal of Ageing Studies 14(2): 135-152.

Laslett, P. (1989). The Fresh Map of Life: The Emergence of the Third Age. London: Weidenfeld and Nicolson.

Moody, H. R. (2001). Productive aging and the ideology of old age. In N. Morrow-Howell, J. Hinterlong \& M. W. Sherraden (eds.), Productive Aging (pp. 175-194). Baltimore: John Hopkins University Press. 
National Programme for the Preparation for Old Age for years 2008-2012, [Národní program přípravy na stárnutí na období let 2008 až 2012]. (Kvalita života ve stárí) Available on http://www.mpsv.cz/cs/5045 (Accessed: June 25, 2010).

Ney, S. (2005). Active ageing policy in Europe: Between path dependency and path departure. Ageing International 30(4): 325-342.

Oancea, A. (2008). The promise of lifelong learning. Ageing horizons 8: 1-3.

Perek-Bialas, J., Ruzik, A. \& Vidovićová, L. (2006). Active ageing policies in the Czech Republic and Poland. International Social Science Journal 58(19): 559-570.

Phillipson, C. (1998). Reconstructing Old Age. New Agendas in Social theory and Practice. London: Sage Publications.

Phillipson, C. \& Powell, J. L. (2004). Risk, social welfare and old age. In E. Tulle (ed.), Old Age and Agency (pp. 17-27). New York: Nova Science Publishers.

Powell, J. L. (2001). Theorizing gerontology: The case of old age, professional power, and social policy in the United Kingdom. Journal of Aging and Identity 6(3): 117-135.

Powell, J. L. (2006). Rethinking Social Theory and Later Life. New York: Nova Science Publishers.

Powell, J. L. \& Biggs, S. (2003). Foucauldian gerontology: A methodology for understanding aging. Electronic Journal of Sociology 17(2). Available on http://www.sociology.org/content/vol7.2/03_powell_biggs.html (Accessed: September 16, 2011).

Rabušic, L. (2008). Senioři a jejich vzdělávání. In M. Rabušicova \& L. Rabušic (eds.), Učime se po celý život? O vzdělávání dospělých $v$ České republice [Do We Learn During Our Whole Life? The Education of Adults in the Czech Republic] (pp. 265-287). Brno: Masarykova univerzita.

Rubinstein, R. L. (2002). The third age. In R. S. Weiss \& S. A. Bass (eds.), Challenges of the Third Age (pp. 29-41). Oxford: Oxford University Press.

Rudman, D. L. (2006). Shaping the active, autonomous and responsible modern retiree: An analysis of discursive technologies and their links with neo-liberal political rationality. Ageing \& Society 26(2): 181-201.

Slowey, M. (2008). Age is just a number? Rethinking learning over the lifecourse. Ageing Horizons 8: 22-30. 
International Journal of Ageing and Later Life

Tulle-Winton, E. (1999). Growing old and resistance: Towards a new cultural economy of old age? Ageing \& Society 19(3): 281-299.

Twigg, J. (2007). Clothing, age and the body: A critical review. Ageing $\mathcal{E}$ Society 27(2): 285-305.

Uhlenberg, P. \& de Jong Gierveld, J. (2004). Age-segregation in later life: An examination of personal networks. Ageing $\mathcal{E}$ Society 24(1): 5-28.

Vidovićová, L. (2005). To be active or not to be active, that is the question: The preference model of activity in advanced age. Ageing International 30(4): 343-362.

Walker, A. (2010). The emergence and application of active aging in Europe. In G. Naegele (ed.), Soziale Lebenslaufpolitik [Social Life Course Policy] (pp. 585-601). Wiesbaden: (VS) Verlag für Sozialwissenschaft.

WHO. (2002). Active aging. A policy framework. World Health Organization. Available on http://www.who.int/ageing/publications/active/en/ index.html (Accessed: September 15, 2010). 